\title{
An Analysis on Adoption of Alternative Rites of Passage for Girls in Elgeiyo/Marakwet County, Kenya
}

\author{
Daniel Kipkorir \\ School of Arts and Social Sciences, Moi University \\ Joram Kareithi \\ School of Arts and Social Sciences, Moi University \\ Donald Wandere \\ School of Arts and Social Sciences, Moi University \\ Eunice Kamara \\ School of Arts and Social Sciences, Moi University
}

\begin{abstract}
Alternative rites of passage are modern cultural practices developed more than two decades ago to substitute the harmful tradition of female circumcision in many parts of Africa. Designed for girls aged 10-16, the model entails teaching teenagers marital skills, physical dangers of female cut, healthcare and prevention of sexually transmitted infections including HIV/AIDS. We carried out a study in 2015 in the Endo Ward of Elgeiyo/Marakwet County, Kenya, to appraise adoption of alternative rite of passage for girls in the region. The Endo Ward is a rural area predominantly inhabited by the Marakwet, a sub-group of Kalenjin speaking people which comprise the Kipsigis, Nandi, Tugen, Keiyo, Pokot and Sabaot. The region was purposely sampled for the study because it is one of the areas that often records high prevalence of circumcision of girls in Kenya. Twenty in-depth interviews, 10 with elderly men and 10 with elderly women, were conducted. The study also employed 10 units of focus group discussion and 16 key informant interviews with alternative rite of passage "teachers", opinion and religious leaders, Non-governmental and community based organizations managers and a medical practitioner. Qualitative data were translated, transcribed, coded, and subjected to thematic analysis and presented in narrative and verbatim form. The study suggests that the Marakwet people of Endo Ward are slow in the uptake of alternative rite meaning that circumcision of girls could continue for long period before it is eradicated. For more adoption of the model, the study recommends more involvement of Marakwet women in the teaching of Marakwet traditional values, adequate support of Marakwet girls who denounce the tradition and a review of the alternative rite of passage programme so as to provide sufficient training on gender roles, and symbolic elements of the community.
\end{abstract}

Key Words: Alternative Rite of Passage, Adoption, Girls, Circumcision, Endo Ward, Elgeiyo/Marakwet County.

\section{INTRODUCTION}

Endo Ward is an administrative unit situated in the northern end of the larger Elgeiyo/Marakwet County, Kenya specifically at $1^{0} 10^{\prime} \mathrm{N}$ to $1^{0} 15^{\prime} \mathrm{N}$, and $35^{\circ} 35^{\prime} \mathrm{E}$ to $35^{0} 40 \mathrm{E}$. It covers an area of $217 \mathrm{Km}^{2}$ with population density of 98 per kilometer square. According to the 2015 Kenya's national census and housing projections, the population of the administrative ward was 24,898 of which 11,745 were men and 13,153 were women. The total fertility rate is estimated at $5.3 \%$ with average life expectancy of $71.4 \%$ for male and $75 \%$ for female. The 
number of people aged 5-16 is projected at 11,834, representing $48 \%$ of the total population of the ward. Of the category 5,756 are young female cohort at high risk of undergoing female circumcision or female genital mutilation (FGM), a ritual which has been outlawed by Kenyan government because of psycho-social and physical dangers it poses. Today, FGM is cited as one of the obstacles to achievement of Sustainable Development Goals (SDGs), which among other targets, seek to reduce maternal mortality rate (MMR) by $75 \%$, combat HIV/AIDS, promote gender equity and women empowerment, attainment of universal primary education and eradication extreme hunger and poverty.

As per the WHO (2010) classification of female circumcision, the Marakwet people in Endo practice type two of the operation. The act entails total or partial removal of the labia minora with or without excision of the clitoris. The ritual, locally called murwo tipiin (circumcision of girls), is performed by elderly women, a majority of whom are traditional birth attendants and specialists in herbal medicine. The entire rite is carried out in four main stages namely, separation (kitung'), the magical cut, seclusion and pass-out (kibuno). All the processes are marked by performances of secret activities (Kibor, 2008; Kipkorir and Welbourn, 2008; Moore, 1996). The rite of passage is largely carried out to train young girls on gender roles, taboos and values which are necessary for marriage and social interaction in the society. Kipkorir and Welbourn (2008) reports that circumcision is of greater importance to the Marakwet people because it provides proper training ground for girls in areas such as housekeeping, or household responsibilities. The rite is also part of an integration system into the membership of the society. The initiates are admitted into an age-set system (ipiin) as mark of identification with the larger society.

In Endo as in other areas, circumcision of girls continues to be denounced by the government, and international organizations. Over the years, the Kenyan government has been harsh on all persons who perpetuate the culture. A number of parents and women circumcisers have been arrested and charged before law court for involment in the circumcision practice. Since 1990s, Non-governmental organizations have been working in Endo Ward to eradicate the culture. For example, the World Vision International has been managing a program for teaching of alternative rites of passage and promotion of girl child education. The organization has been operating through the local churches, and in particular, the Anglican Mission, to support Marakwet poor households with education and protection of girls from forced circumcision (The World Vision Kenya Report, 2007). A World Vision Report (2009) indicates that most of the Marakwet households are fully aware of alternative rite of passage program. When the project ended in 2008, the alternative rites work was taken over by two community based organizations, Tumdo Ne Neel (TNL), and the Marakwet Girls and Women Organization (MGWO).

Despite introduction of the alternative rite, recent statistics showed that prevalence of female circumcision in Elgeiyo/Marakwet County stands at 28\%, which is still very high according to the government and international organization's view (Government of Kenya: Demographic and Health Survey, 2012-2014; Achia, 2014). Very few Marakwet families send their girls for training but opt for the traditional ritual which involves the cut, seclusion and teaching for a month. Persistence of female circumcision ritual indicates a deeply-rooted culture that is not easy to eradicate (Kibor, 2008). This paper assesses the extent to which the alternative rite has been adopted by the Marakwet people.

\section{METHODOLOGY}

The study was largely qualitative. It was undertaken in May-December 2015 in five sublocations in the Endo Ward namely, Barakelat, Kaben, Kapkondot, Kisiwei and Sibow. The 
administrative units were purposely sampled in line with objective of the study. Sibow SubLocation, for example, was chosen because the residents here have largely interacted with outsiders for a long time. The sampling was based on assumption that residents of Sibow SubLocation have been largely influenced by foreign culture hence embrace the alternative rite more than other people in the study area.

Purposive sampling was also employed to select respondents for in-depth and key informant interviews. A total of 20 respondents for in-depth interviews were selected by purposive sampling and accessed through the snowball sampling technique. The sample comprised elderly men and women aged 70 and above. The group was targeted because they are more knowledgeable on Marakwet culture and traditions. Being the custodians of Marakwet heritage, the group was in a better position to answer the research questions. Most of the women interviewed were circumcisers, traditional birth attendants and herbalists. The key informants selected included alternative rites of passage "teachers" or instructors, opinion leaders, community based managers, religious leaders, law enforcers and medical practitioner. In each sub-location, two focus group discussions, one for men and the other for women were conducted. Separation along gender lines was necessary because in the Marakwet culture circumcision is secret affair. Female circumcision is covert to women while male circumcision is covert to men but each sex knows few secrets of the other. Each group comprised of 6-8 people who have been initiated and are knowledgeable on the Marakwet culture. Informed consent was obtained from the participants before the start of the interviews and discussions. Qualitative data was transcribed, coded, and classified into thematic areas. The content was then analysed thematically. The results were then presented in form of narratives and verbatim.

\section{THE ALTERNATIVE RITE OF PASSAGE PROGRAMME TAUGHT IN ENDO WARD}

Currently, there is one program in use in Endo region. The alternative program evolved from tensions between Marakwet people and government over circumcision of girls. Because the Marakwet female circumcion function to educate girls on marital skills, adulthood roles and character values, alternative rite was introduced in Endo Ward as alternate for the harmful ritual. The curriculum has been reviewed several times by stakeholders involved in anti-female circumcision campaigns. The one which is currently in operation is administered by Tumdo $\mathrm{Ne}$ Leel, a community based organization. The course consists of 9 topics, each with more than four sub-topics (Table I). 
Table I: Structure of Alternative Rite of Passage Curriculum in use in Endo Ward Introduction and Biblical Approach to Circumcision

Traditional Rites of Passage and Taboos

Birth Rites, Naming Rites, Initiation Rites, Marriage Rites, Burial Rites

Body Changes and Development

Reproductive Organs, On-set of Puberty, Adolescence Behaviour, Habits and Dressing

Heterosexual Relationships and Marriage

Engagement, Marriage and Adult Life, Pregnancy and Birth, Child Birth and Care

Family Care and Housekeeping

Provision of Food Clothing and Shelter, Food Preparation, Diet and Nutrition

Self-Concept and Esteem

Decision-Making, Coping with Peer Pressure, Spiritual Growth and Development

Empowerment and Rights in Society

Setting Personal Goal, Education and Career, Alternative Sources of Income

Achieving Set Goals, Productive use of Leisure Time, Children and Women Rights

\section{Health care and Disease Prevention}

Personage Hygiene, Reproductive Health, Contraception and Prevention of Sexually Transmitted

Diseases and HIV/AIDS, Early Pregnancy, Prevention of Malnutrition

Mass Media and Drug Abuse

\section{Morals and Ethics}

Respect, Courtesy, Love, Sympathy, Generosity

According to the instructors of the program, the curriculum was properly designed to guide the Marakwet girl in social interactions within and wider Kenyan society. The topics are considered to be more relevant for the Marakwet girl child today than before because of the new cultural and economic challenges. In the training, there is no time period allocated to each of the topics. An introduction on biblical approach to circumcision is first provided because the Marakwet people in Endo are predominantly Christians (mostly Roman Catholics and Anglicans) even as they continue to practice indigenous initiation rites. In this training, the girls are informed that circumcision is an outdated ritual which does not add value to the lives of those who seek for it. Apart from promoting spiritual growth, this approach helps the girls to understand worthlessness of female circumcision. In the teaching, healthcare and disease prevention is emphasized because teenage pregnancy and sexually transmitted infections (STIs) including HIV and AIDS is highly prevalent in the ward today. Since 1992 when the first case of HIV/AIDS was reported in the area, the prevalence rate of the disease has increased from $0.013 \%$ to 6\% (Government of Kenya: Demographic and Health Survey, 2012-2014).

The program provides an open discussion with the girls. They are able to attain knowledge in sexual matters, especially how to interact with men in "a careful manner". Moreover, they are educated on hygiene, and safe sex using condoms and anti-pregnancy pills. An alternative rite of passage teacher indicated:

This is crucial today because girls are more exposed to sex in early age than in the past. As girls reach the age of 8-14 serious preparation must be made to ensure that they are conversant with many sexual issues which may affect their lives. This forum is used to instill values for education so that girls are empowered hence bridging the gap.

The instructors interviewed indicated that parents are free to send their daughters to the teaching camp at Kapkondot during the December holiday. To emulate the local Marakwet custom of initiation, girls are secluded in the training center for five days. Respondents 
indicated that many families are unable to bring their girls for teaching exercise because of high transport costs. The training point at Kapkondot near Chesongoch centre is too far for girls from Kaben, Barkelat, Kisiwei, Sibow Sub-Locations and other areas to attend. For the one week or so, girls who report to the center are well taken care of. They are provided with adequate food, medical care and accommodation for free.

\section{TEACHING OF ALTERNATIVE RITE OF PASSAGE IN ENDO WARD}

The study found that girls are orally taught some topics for the whole period in the camp. According to the instructors, face-to-face interaction provides more discussion on female cut issue. One of the "teachers" interviewed explained:

We tell them that circumcision of girls is bad. If the issue is that you cannot be married here in the Marakwet community because you are not circumcised, then the world is very wide. There are men in other communities who are ready to marry uncircumcised women. Out there you will find the Luyia, Luo, and Turkana men ready to marry uncircumcised women. We tell them that they can be married abroad by Europeans (Chumba)...We tell them that the world is now a global village. With education, a woman can migrate, live and work anywhere and interact with various cultures which do not care much about circumcision.

Girls from age of 14 and above are shown pictures on the physical effects of female circumcision to enhance their understanding of the dangers of the ritual. The respondents stated that girls in this age group are able to interpret the information well. It is assumed that by using this method, girls will be disheartened from seeking the cut and also pass the information to peers. Another alternative rite of passage instructor in Kapkondot Sub-Location explained:

We often use pictures to enable girls see bad side of female genital mutilation. You know this practice is awful because many girls have contracted HIV/AIDS and even hepatitis B. A number have died from excessive bleeding and shock while some have dropped from school and got married in tender age. Circumcised women also continue to experience prolonger labour at home and even in hospital. Today, you cannot teach without showing learners 'clips' on what you want to emphasize. We want the girls to capture the message well. In fact, images speak better than words because girls can actually see what we are telling them by simply looking at picture to understand how the cut damages the female body. We use pictures not only from the Marakwet community but from Pokot, Keiyo, Samburu, Somali, and other ethnic groups which still circumcise girls.

Besides, motivational talks are arranged during the "graduation" day. Educated women from different Kenyan ethnic groups which circumcise girls are invited to give the girls more talks on dangers of female circumcision, unsafe sex, and importance of formal education as well as career paths. According to the respondents, the activity is executed with the assumption that girls would work hard in their studies and emulate the speakers in terms of professions.

\section{FITTING THE MARAKWET SOCIETY WITH THE ALTERNATIVE RITE OF PASSAGE MODEL}

The participants in key informant interviews indicated that alternative rite is a good program because it allows more girls to pursue education to higher levels. A large number of girls who ignored circumcision and adopted alternative rites of passage have continued with their studies up to the university level. This suggests that the new ritual is significant for achievement of sustainable development goals, in particular, universal primary education, and eradication of hunger and poverty because after completing studies, girls are able to compete for employment opportunities within and outside the country. The research finding concurs 
with Achoka (2007) study that female circumcision is one of the factors contributing to high dropout of girls in Kenya's primary and secondary schools. Upon graduation from circumcision ritual, girls are immediately married off because they are considered mature enough for reproduction. In Endo Ward, 30.5\% of girls in primary schools drop out after undergoing circumcision. The drop in secondary schools stand at 25\% (Marakwet Sub-county Report: Ministry of Education Kapsowar, 2014).

In the alternative rite of passage program, a number of girls from poor households are also supported by NGOs and the church. With the financial assistance, most have been able to join Kenyan and foreign universities but the problem is that when they come back to the society, they remain unmarried for long because most of the Marakwet men still observe taboo of not marrying uncircumcised women. In the end the ladies are forced to undergo the cut so as to be married. Others opt to seek partners in other Kenyan ethnic groups such as the Luyia, Luo and Turkana but most of the Marakwet people are unhappy about this inter-ethnic marriage. The community feel they are losing their women to "foreigners" who do not value circumcision. They argue that ethnic groups such as the Luo do practice strange rituals such as wife inheritance (mulatakor) and sororate marriage (kachebikot). In the Marakwet culture, wife inheritance is regarded incestuous. The community holds that wife inheritance does not promote high exchange of genes in the larger Marakwet nation. In addition the marriage is weak in building strong inter-clan alliances through exchange of women and bride-wealth. It is for this reason that the Marakwet allow a widow to remarry outside the clan if she is still young or did not beget children with the deceased. Most of the in-depth respondents indicated that inter-ethnic marriage will threaten the Marakwet cultural values, norms, and beliefs. Today, the Marakwet preferred to intermarry with few Kenyan ethnic groups such as the Pokot, Sabaot, Tugen, Keiyo, Kipsigis,Abagusii, Agikuyu, Maasai, Somali and Samburu. All these communities still practise female circumcision and are thus seen to be in same social status with the Marakwet people. From an outsider's point of view, the new inter-ethnic marriage has promoted national integration.

A number of key informants expressed that the program is good because teaching is juxtaposed with modern knowledge and skills that are necessary for survival. The girls are taught life skills that are required in the modern world. They are taken through lessons which touch on moral behaviour and spirituality. A religious leader interviewed indicated:

This training should be embraced by all the Marakwet households. It is an integrated program that enables girls graduate to adulthood wholesomely. The teaching is important for Christian spiritual growth and promotion of girl child education. It has imparted good values such as education and healthcare. The Anglican Church has been supporting the programme here in Endo Ward since the year 2005. We have been visiting the training centers to encourage girls to study hard and join the higher institutions of learning. Today, I am happy because a number of girls have graduated from university and colleges. In order for the girls to maintain the status, another forum is needed for encouraging time to remain uncut. A number of alternative rite of passage alumni continue to be lured into circumcision in adult stage because their husbands are influenced by members of the community to subject their wives to cut. Recently two university graduates in Kasek village were circumcised during labour and secretly secluded for weeks. We as Christians felt that more should be done to improve on the alternative rite to counter this problem.

Compared to the indigenous Marakwet female circumcision ritual, alternative rite of passage is cheaper for parents. The girls are provided with sufficient food, accommodation and medical care while in the camps for free. In the traditional rite, the father of the neophyte often gives 
out a goat or sheep for slaughter for each girl. Besides, he is required to provide two "maize meal", tea or porridge a day for the initiates and masters of the circumcision until graduation day. Each household also prepares local drinks (maiywa) for entertainment. Parents who no longer circumcise their daughters are now relieved from the above expenses. They are able to utilize the surplus grain and livestock in education and healthcare costs. The Endo region is semi-arid zone that experience little rainfall of $600 \mathrm{~mm}$ per annum. Though the soils are fertile, crops are mainly grown by irrigation using traditional furrows constructed about five hundred years ago from perennial rivers such as Embobut, Enou, Oloot, and Chesegon. Access to water for irrigation is limited hence most of the households are affected by hunger forcing them to seek for relief food from the government and international organizations (Kipkorir and Kareithi, 2013). The alternative rite of passage program indirectly gears up for utilization of household food resources hence reduction of shortage of food.

\section{ADOPTION OF ALTERNATIVE RITE OF PASSAGE RITUAL AMONG MARAKWET PEOPLE IN ENDO WARD}

The analysis showed that adoption of alternative rite in Endo Ward is still low. The key informants indicated that from 1997-2014, an estimated 4,050 girls out of 24,000 participated in the alternative rite In 2012-2014, about 600 girls participated in the ARP, 520 participated in 2009-2011, a total of 680 were trained in 2006-2008. The total number in 2003-2005 period was 750, a total of 800 in 2000-2002 while 700 participated in 1997-1999. In the 2012-2014 cohort, 20 girls from Kaben Sub-Location participated in the alternative rite, 20 participated in Barkelat, 15 in Kisiwei, 30 in Sibow and 40 in Kapkondot.

It was pointed out that during the same period, 15 girls who underwent the alternative rite later changed their mind and decided to undergo female circumcision or FGM in Kaben SubLocation, 16 girls were cut in Barkelat Sub-Location, 14 in Kisiwei Sub-Location, 26 in Sibow Sub-Location, and 35 in Kapkondot Sub-Location. In the analysis a small group (of 18\%) only remained uncircumcised after undergoing the alternative rite program. The study shows that girls from protestant Christian households abstain from the ritual after they are converted. This pattern was also observed in Muranga County in Kenya where the Anglicans totally speak against the culture while the Catholics continue to circumcise their daughters (Gachiri, 2000). The Catholic Church established firm root in Endo in the 1970s because of their minimal interference with the Marakwet cultural values and traditions which include circumcision and traditional wedding ritual (tum).

A number of reasons were given as to why the adoption of the program is still low in the region. A female in-depth respondent aged 75 years from Kaben Sub-Location indicated:

Life without circumcion of girls is both good and bad. Today it is possible to withdraw from the custom and pursue education, get employment and be rich. You can buy land in an urban area, a car, or a building. But it is also a disaster to ignore the practice because it directs you and your offspring in social interaction. In Kabox (the alternative rite), girls are not taught the rules of inter-clan marriage (koyier). When we abandon the circumcision of girls, many of our grand children will in future marry within the clan. We hear that all the alternative rite of passage instructors are outsiders from Keiyo, Tugen and Nandi. What do they know about the Marakwet culture...?

Most of the respondents in the in-depth interview argued that circumcision of girls should be respected even if dangers are there because it provides effective training. Those in favor of the practice say the culture has been practiced since time immemorial and is thus significant in distinguishing the community from other cultures. It was indicated that the Marakwet female 
circumcision ritual processes for instance genital cut (murwo), kiborusko, tangat, kimaket, yaswa and kibuno are left out of the alternative rite yet the activities are core in the female cut ritual.

Every Marakwet male and female has to undergo circumcision ritual so as to be considered not only an adult but also a member of the community. Despite all risks, female circumcision is still popular in the community because it brings social recognition of a woman to be eligible for all social interactions. The indigenous rite is valued over the modern rite since the operation is believed to make a woman physically pure and attractive for marriage. Being circumcised is more dignified than remaining uncut hence all those who have not undergone the ritual are ostracized in marriage. Respondents indicated that after cut, a woman becomes Cheros (sexually pure person) or Korka (wholesome woman) meaning ripe for marriage, birth and participation in communal roles. In the Marakwet community, negotiation for marriage and bride wealth begins immediately girls undergo circumcision. Since they are kept in seclusion for weeks, most are not aware of what transpires between their parents and suitors.

According to the respondents, the alternative rite does not resolve the Marakwet structural thought of "purity" because the girls are not cut. The Marakwet believe that circumcision is the only way a girl should undergo in order to become a member of the community. This finding concurs with Oloo et. al (2014) report that among the Abagusii and Abakuria communities, "social acceptance" is the main force behind participation of girls in circumcision ritual.

Findings in focus group discussions indicated that in the alternative rite, small things like disciplining the girl, instilling bravery and combative skills is not adhered to. Discipline and bravery is still very much valued in the Marakwet community because it enables a woman to safeguard her family from hostility within and outside the society. This assertion is in line with study by Kibor (2008), Kipkorir and Welbourn (2008) that Marakwet people place great importance to harsh training of girls and boys. This is done to prepare the youth for responsibilities and challenges in life. In both female and male circumcision rituals, the Marakwet employ harsh training for neophytes. Respondents indicated that girls who have undergone the Marakwet female circumcion are more courageous compared to those who have undergone the alternative rite.

Unlike the traditional fashion, the alternative rite does not provide space for communication of kinship ties in the community. The alternative rites of passage "graduates" do not know who is socially related to whom in the society, thus clan and lineage identities are not fostered as expected. In the community, knowledge on the social ties is significant for maintenance of exogamous marriages between the clans. Further, the alternative rite does not micmic the traditional ritual because "neophytes" are not conferred an age-set name. The female age-set is very important in Marakwet society because it acts as a fulcrum for regulating marriage across age-groups and maintenance of unity among women. Distinct from other Kalenjin sub-groups, a Marakwet woman marries to corresponding male age-set structure for example the Tabesit female age-set is expected to marry Kaberur male age-set while Sigin-gin marry Korongoro ageset. This structure is maintained to deter huge age disparity. The community hold that a big age difference among couples affects health of the offspring. An old person is believed to have weak sperm or ova and thus cannot marry a young individual.

Compared to the traditional circumcision, the time for training in alternative rite training is short. In the focus group discussion, the consensus was that the period is inadequate hence does not allow girls to learn more about adulthood roles and the Marakwet taboos and norms. The girls are rushed through the program for a few days, which is not enough to deliver all the 
knowledge expected in adulthood. Teaching in the Marakwet circumcision ritual lasts for one month with use of songs and proverbs.

The response from focus group discussions was that the alternative rite is unethical because it uses genital pictures for teaching on effects of female circumcision. Public display of genitalia is a taboo in the Marakwet culture because it breaches the notion of "holiness" of the human body. The taboo is meant to safeguard secrets of circumcision from those who have not undergone the ritual. A respondent indicated that better ways of expression should be sought to deliver the message. The "teachers" or facilitators of the alternative rite seem to be ignorant on the negative effect of pictures on the Marakwet culture.

\section{CONCLUSION}

In the study, it was established that the uptake of alternative rite of passage is still low. For the program to succeed, the NGOs and CBOs need to build up a strong team of Marakwet women facilitators to implement the programe. Since the ritual is intertwined with strong common beliefs, there is also need to involve the community elites as well as the Christian society to debunk traditional beliefs of the tradition. Further, the alternative rite of passage program should be reviewed so as to capture teaching of clan, ethnic and national identities. This chain of character is significant for social interaction and unity at local and national levels.

\section{ACKNOWLEDGEMENT}

Part of this study was funded through a grant from the Templeton World Charity Foundation, Inc. (TWCF 0151). The opinions expressed in this publication are those of the authors and do not necessarily reflect the views of Templeton World Charity Foundation, Inc. The work was also financially supported by Moi University. The authors are indebted to both organizations but much more to all study participants (who remain unnamed for ethical reasons) for their invaluable contribution to this study.

\section{References}

Achia, T. (2014) Spatial Modeling and Mapping of Female Genital Mutilation in Kenya. Journal of Public Health, 14; 276

Achoka, J. S (2007) In Search of Remedy to Secondary School Dropout Pandemics in Kenya. The Role of the principal. Education Research and Review. Vol 2 (3) ISSN 2240-0524

Gachuri, E W (2000) Female Circumcision. Nairobi: Pauliness

Government of Kenya: Demographic and Health Survey 2012-2014.Nairobi: Government Printer.

Government of Kenya: Marakwet Sub-County Report 2015: Kapsowar. Ministry of Education.

Government of Kenya: :The Children Act (2001). Principles of the Convention on the Rights and Welfare of the African Child. Nairobi: Government Printer.

Government of Kenya: The Kenyan Constitution (2010). Nairobi: Government Printer.

Kibor, J. (2008). Christian Response to Female Circumcision: A Case study of the Marakwet of Kenya. Nairobi: Evangel.

Kipkorir, B. and Welbourn, F. (2008). The Marakwet of Kenya: A Preliminary Study. Nairobi: East African literature Bureau.

Kipkorir, D and Kareithi, J (2013) Indigenous Irrigation and Food Security in Tot Division, Kerio Valley, Kenya. Journal of Anthropology and Archeology 1 (1) 01-20

Moore, H. (1996). Space, Text and Gender: An Anthropological Study of the Marakwet of Kenya. Cambridge: Cambridge University.

Oloo, H. Wanjiru, M. and Newell-Jones, K. (2011) Female Genital Mutilation Practices in Kenya: The Role of Alternative Rites of Passage; A Case Study of Kisii and Kuria Districts. : London. Comic Relief Report. 
WHO (2010). Factsheet: Female Genital Mutilation. Geneva: WHO.

World Vision Kenya and Finland (2007) Female Genital Mutilation: Girl Child Empowerment through Alternative Rites of Passage. Nairobi: World Vision.

World Vision Kenya (2009) Tot Anti-Female Genital Mutilation Project Report. Nairobi: World Vision. 